\title{
Stability and maturity of maize stalks compost as affected by aeration rate, $\mathrm{C} / \mathrm{N}$ ratio and moisture content
}

\author{
W. M. Nada \\ Department of Soil Science, Faculty of Agriculture, Menoufia University, Shebin El-Kom 32514, Egypt. \\ *Corresponding author:wael_nada22@yahoo.com
}

\begin{abstract}
To estimate the order of importance of factors affecting the stability and maturation of compost, cow feces and maize stalks were co-composted at different aeration rates "AR" $\left(22,44\right.$ and $66 \mathrm{~L} \mathrm{~kg}^{-1} \mathrm{DM}$. min"-1) of C/N ratios $(16,19,22)$, and moisture contents "MC" (60\%, $65 \%, 70 \%)$. A composting process was monitored by physical and chemical methods. The thermophilic phase with all treatments was long enough to meet sanitation requirements. The emitted carbon dioxide and the losses total organic carbon and total extractable carbon increased with increasing aeration rate, there was a significant difference between the treatments with low and high aeration rate, but no significant differences between those two treatments and the moderate aeration rate. The total nitrogen contents of all treatments decreased during the thermophilic phase, while it was increased after that for all treatments except $\mathrm{T} 8$. The compost with the highest initial $\mathrm{C} / \mathrm{N}$ ratio was significantly different from the other treatments and had the highest values of humic substances, degree of humification and humification rate. The compost with the lowest initial $\mathrm{C} / \mathrm{N}$ ratio was significantly different from the other treatments and had the lowest germination index (57-67\%). Aeration rate was the main factor influencing compost stability, while the $\mathrm{C} / \mathrm{N}$ ratio mainly contributed to compost maturity, and the moisture content had an insignificant effect on the compost quality. The recommended parameters for composting are an aeration rate of $0.44 \mathrm{~L} \mathrm{~kg}^{-1} \mathrm{DM}$. min'-1 and a carbon to nitrogen ratio of 19 with moisture content of $60-70 \%$.
\end{abstract}

Keywords: Composting, agricultural waste, compost, quality, stability, maturity

\section{Introduction}

The amount of cow waste generated in Egypt has increased dramatically with the rapid development of cow farms. These wastes can cause hygiene hazards, odor pollution, and ground and surface water pollution from the leaching of pollutants, if not properly treated. Also, increased use of animal waste has brought hygienic aspects into focus, particularly the need to significantly reduce pathogen content. Manure composting involves the breakdown of complex and simple organic materials by aerobic microorganisms (Novinscak et al, 2007). On the other hand, agricultural wastes in Egypt are considered a big problem facing farmers and officials. The amount of these wastes is about 14 million tons annually. These amounts of crop residues are burnt in several governorates. It is environmentally undesirable and is practiced by farmer. Average crop residues of maize stalk in Egypt are 4.1 million tons 
(Badawi and Tantawi, 2004). Bulking agents are always required to modify the properties of animal manure during composting because of the high moisture contents, low $\mathrm{C} / \mathrm{N}$ ratio and high density of animal manure. The maize straw is rich in carbon and has a low density and low moisture content, making it suitable for use as a bulking agent during composting (Kumar et al, 2010).

As an agricultural country, Egypt needs large amounts of organic fertilizers to improve crop yields and quality, and maintain or increase the nutrient status of soil and improve its structure. Fresh cow feces are a valuable resource for organic fertilizers because of their high organic matter and nutrient content. However, fresh cow waste is unsuitable for direct land application because of the unstable organic matter, pathogens, weed seeds and the difficulties associated with preservation and transportation. Composting is an effective and economical method for the treatment of animal manure prior to land application, in which pathogens and weed seeds are destroyed and the highly heterogeneous solid state organic matter is transformed to more stable and mature humic substance by the activity of bacteria, epiphytes and actinomycetes (Badawi and Tantawi, 2004). Also, stable and mature compost can be applied to soil as an organic amendment to improve plant growth and soil fertility, as well as enhancing the function of soil for carbon sequestration. However, the application of unstable and immature compost would fix nitrogen in the soil and restrict plant growth by competing for oxygen in the rhizosphere and releasing toxic substances (Bernal et al, 2009).

The stability and maturity of compost are often referred to as the compost quality. The stability typically refers to microbial activity and can be defined by the emitted carbon dioxide, the heat released, respiration index or the conversion of various chemical species in compost organic matter
(Gao et al, 2010), while maturity refers to the amount of degradation of phytotoxic organic substances and is generally measured by the germination index or plant bioassays (Said-Pullicino et al, 2007). However none of these methods give an absolute parameter. Compost is a very heterogeneous biomass and the different chemical methods exploited to determine maturity level are only suitable for certain families of materials. Govi et al. (1993) reported a poor correlation between the degree of humification (DH), compost protein and hemicelluloses rich materials due to the formation of humic-like molecules. While Marco et al. (2004) found a high correlation between humification parameters and water-soluble carbon (WSC) that is possible to monitor the composting maturation process more easily and rapidly avoiding longer and more expensive analytical procedures.

The aeration rate (AR) is considered to be the most important factor influencing successful composting (Diaz et al, 2002). Insufficient aeration can lead to anaerobic conditions due to the lack of oxygen, while excessive aeration can increase costs and slow down the composting process via heat, water and ammonia losses. The optimal AR depends on the composition of the raw materials and ventilation methods (Bernal et al, 2009; Shen et al, 2011).

The initial carbon to nitrogen $(\mathrm{C} / \mathrm{N})$ ratio is one of the most important factors influencing compost quality. In general, initial $\mathrm{C} / \mathrm{N}$ ratios of 25-30 are considered ideal for composting (Kumar et al, 2010). However, recently some researchers have successfully carried out composting at lower initial $\mathrm{C} / \mathrm{N}$ ratios (Ogunwande et al, 2008). Composting at lower initial $\mathrm{C} / \mathrm{N}$ ratios can increase the amount of manure treated, but can also increase the loss of nitrogen as ammonia gas. During composting, the moisture content (MC) is important for transporting the dissolved nutrients required for the physiological and metabolic activities of microorganisms. The optimum MC depends on the 
specific physicochemical properties and biological features of the materials being composted (Liang et al, 2003).

The interaction of these factors on composting has recently been studied by some researchers. The optimum MC was $60 \%$ during the composting of green waste and food waste at a low $\mathrm{C} / \mathrm{N}$ ratio (19.6) (Kumar et al, 2010), while and the optimum conditions for the composting of poultry manure with wheat straw were an initial MC of $70 \%$ and an AR of $0.54 \mathrm{~L} \mathrm{~min}^{-1} \mathrm{~kg}^{-1} \mathrm{OM}$ (Petric and Selimbašic, 2008).

Although several researchers have studied the effects of $\mathrm{AR}, \mathrm{C} / \mathrm{N}$ ratio and $\mathrm{MC}$ on the quality of compost, they have focused on one or two influential factors, with few studies designed to address the interaction and order of preference for different factors impacting the composting process. Therefore, an orthogonal test was used to investigate the main factors affecting the stability and maturity of composted cow manure and maize stalks; AR (0.22, 0.44 and $0.66 \mathrm{~L} \mathrm{~kg}^{-1} \mathrm{DM}$ min1, DM: dry matter); $\mathrm{C} / \mathrm{N}$ ratio (16, 19 and 22) and $\mathrm{MC}$ $(60 \%, 65 \%$ and $70 \%)$.

\section{Materials and Methods}

\subsection{Feedstocks composition}

This study was carried out at the beginning of March 2013 in greenhouse of the Experimental Farm, Faculty of Agriculture, Menoufia University, Shebin El-Kom, Egypt. Cow feces were taken from a cow farm located in Faculty of Agriculture, Menoufia University. The feces were collected on three consecutive days before the trial started. Maize stalks were obtained from a research station at the Faculty of Agricultural, Menoufia University. The maize stalks were passed through a cutting mill by using threshing machine to generate pieces ranging from 1 to $5 \mathrm{~cm}$. The moisture content (MC), total organic carbon (TOC), total nitrogen (TN), $\mathrm{C} / \mathrm{N}$ ratio and total extractable carbon (TEC) of the feed stocks were determined before mixing to determine nitrogen ratios to be applied. The properties of compost raw materials were carried out according to Page et al. (1982) and the obtained data are shown in Table 1.

Table 1. Some properties of cow feces and maize stalks.

\begin{tabular}{cccccc}
\hline Materials & $\begin{array}{c}\text { Moisture } \\
\text { content }(\%)^{\mathrm{a}}\end{array}$ & $\begin{array}{c}\text { TOC } \\
\left(\mathrm{gkg}^{-1}\right)^{\mathrm{b}}\end{array}$ & $\begin{array}{c}\mathrm{TN} \\
\left(\mathrm{gkg}^{-1}\right)^{\mathrm{b}}\end{array}$ & $\begin{array}{c}\mathrm{C} / \mathrm{N} \\
(-)\end{array}$ & $\begin{array}{c}\text { TEC } \\
\left(\mathrm{gkg}^{-1}\right)^{\mathrm{b}}\end{array}$ \\
\hline Cow feces & $70.52(1.5)^{\mathrm{c}}$ & $353(5.82)$ & $26.50(0.06)$ & 13.32 & $180.5(6.63)$ \\
Maize stalks & $8.33(0.01)$ & $425(8.30)$ & $10.30(0.12)$ & 41.26 & $209.7(7.42)$ \\
\hline
\end{tabular}

${ }^{\mathrm{a}}$ Wet weight basis, ${ }^{\mathrm{b}}$ Dry weight basis, ${ }^{\mathrm{C}}$ Values in parentheses are standard errors $(n=3)$

\subsection{Experimental set-up and design}

The composting reactors were $45 \mathrm{~L}$ plastic cylinders (57 cm high and $32 \mathrm{~cm}$ inner diameter) (Fig., 1). The vessels were consisted of two layers of plastic intermediated with a layer of glass wool to minimize heat loss. A removable plastic lid was fitted to the top of each vessel to facilitate filling with feed stocks and removing compost. On the lid, there were holes for inserting a temperature sensor and to connect the carbon dioxide trapping solution. The temperature sensor was connected to a temperature data logger (HI143 T-Logger) to auto-record the data. At the bottom of the reactors, a $3 \mathrm{~mm}$ plastic grid was installed to support the composting bed and insure uniform gas distribution. There were two holes in the 
bottom of the reactor for aeration (using a controllable aquarium pump) and leachate drainage.

This study was established as an orthogonal array test $\mathrm{L}_{9}\left(3^{4}\right)$ lasting 60 days (Table, 2). Cow feces and the chopped maize stalks were mixed manually in different amounts to adjust the $\mathrm{C} / \mathrm{N}$ ratios at 16,19 or 22 , and the initial MC values to $60 \%, 65 \%$ or $70 \%$. Super phosphate $\left(15.5 \% \mathrm{P}_{2} \mathrm{O}_{5}\right)$ was mixed with all vessels by $7.0 \mathrm{~kg} /$ ton of each vessel as amendment. The ARs were $0.22,0.44$, and $0.66 \mathrm{~L} \mathrm{~kg}^{-1} \mathrm{DM}$ min 1. Air is entered through the compost mixture by aquarium pump. The aeration of all treatments was intermittent with $25 \mathrm{~min}$ of aeration followed by 5 min without aeration over the whole composting period (60 days). The compost vessels were turned on days $3,7,15,30$ and 45 .

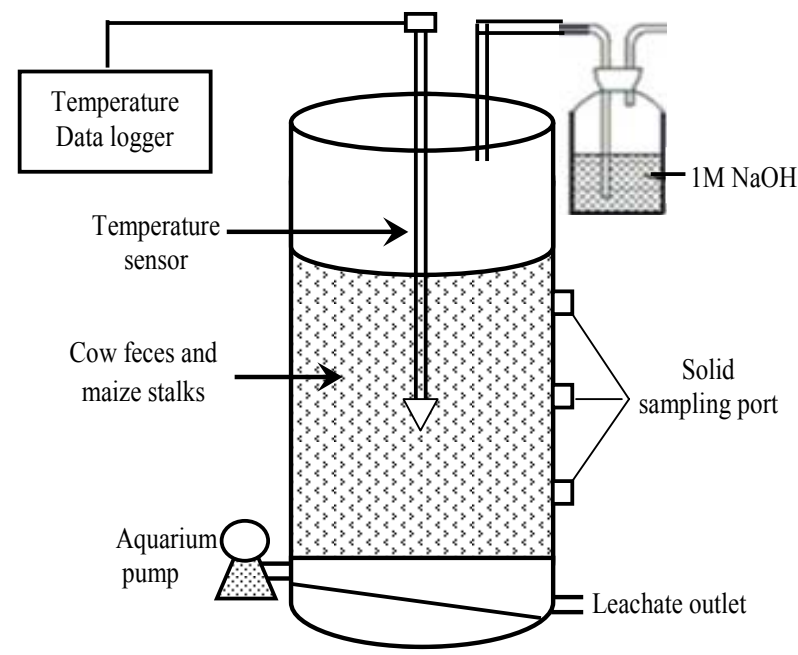

Figure 1. Schematic Diagram of the composting vessel.

Table 2. Design of experiment

\begin{tabular}{|c|c|c|c|}
\hline Treatments & $\begin{array}{c}\text { Moisture content } \\
(\%)\end{array}$ & $\begin{array}{c}\text { Aeration rate } \\
\left(\mathrm{L} \mathrm{kg}^{-1} \mathrm{DM} \mathrm{min}\right. \\
\end{array}$ & $\begin{array}{c}\mathrm{C} / \mathrm{N} \text { ratio } \\
(-)\end{array}$ \\
\hline $\mathrm{T} 1$ & 60 & 0.22 & 16 \\
\hline $\mathrm{T} 2$ & 60 & 0.44 & 19 \\
\hline T3 & 60 & 0.66 & 22 \\
\hline $\mathrm{T} 4$ & 65 & 0.22 & 19 \\
\hline T5 & 65 & 0.44 & 22 \\
\hline T6 & 65 & 0.66 & 16 \\
\hline $\mathrm{T} 7$ & 70 & 0.22 & 22 \\
\hline $\mathrm{T} 8$ & 70 & 0.44 & 16 \\
\hline T9 & 70 & 0.66 & 19 \\
\hline
\end{tabular}

a Aeration for $25 \mathrm{~min}$, no aeration for $5 \mathrm{~min}$ 
Table 3. Total organic carbon (TOC) and total nitrogen (TN) mass balance at the end of composting

\begin{tabular}{cccc|ccc}
\hline & \multicolumn{3}{c|}{ Total organic carbon (TOC) } & \multicolumn{3}{c}{ Total nitrogen (TN) } \\
\cline { 2 - 6 } Treatment & $\begin{array}{c}\text { Initial } \\
\left(\mathrm{g} \mathrm{kg}^{-1} \mathrm{DM}\right)\end{array}$ & $\begin{array}{c}\text { Final } \\
\left(\mathrm{g} \mathrm{kg}^{-1} \mathrm{DM}\right)\end{array}$ & $\begin{array}{c}\Delta \mathrm{TOC}^{\mathrm{a}} \\
(\%)\end{array}$ & $\begin{array}{c}\text { Initial } \\
\left(\mathrm{g} \mathrm{kg}^{-1} \mathrm{DM}\right)\end{array}$ & $\begin{array}{c}\text { Final } \\
\left(\mathrm{g} \mathrm{kg}^{-1} \mathrm{DM}\right)\end{array}$ & $\begin{array}{c}\Delta \mathrm{TN}^{\mathrm{b}} \\
(\%)\end{array}$ \\
\hline T1 & 369 & 315 & 44 & 23 & 27 & 22 \\
T2 & 382 & 310 & 51 & 20 & 27 & 28 \\
T3 & 398 & 345 & 54 & 18 & 26 & 32 \\
T4 & 384 & 335 & 42 & 20 & 25 & 23 \\
T5 & 404 & 361 & 56 & 18 & 28 & 29 \\
T6 & 372 & 301 & 51 & 23 & 24 & 45 \\
T7 & 406 & 360 & 47 & 18 & 26 & 19 \\
T8 & 375 & 334 & 36 & 23 & 19 & 40 \\
T9 & 385 & 332 & 50 & 20 & 25 & 36 \\
\hline
\end{tabular}

${ }^{a}$ Based on initial carbon content, ${ }^{\mathrm{b}}$ Based on initial nitrogen content

\subsection{Sample collection and analytical methods}

Solid samples (about $200 \mathrm{~g}$ ) were taken at the beginning, after each turning and end of composting. Five grams of each sample were taken for MC determination by drying at $105^{\circ} \mathrm{C}$ to a constant weight. The remainder sample was divided into two parts. The first part stored at $4{ }^{\circ} \mathrm{C}$ and the second part was air-dried and grounded to pass through a $2 \mathrm{~mm}$ sieve. The dried and ground samples were analyzed in triplicate for total nitrogen (TN), total organic carbon (TOC) and total extractable carbon (TEC), humic-like acid fraction (HA) and fulvic-like acid fraction (FA). TOC was determined by the Walkley-Black Method; $\mathrm{TN}$, by indophenols-blue method after the Kjeldahl digestion (Page et al, 1982).

Humic-like substances were extracted from the compost samples as described by Ciavatta et al. (1990) and the total extractable carbon (TEC) determined by wet dichromate oxidation. The extracts were fractionated into humic acids (HA) and fulvic acids (FA). After purification, the carbon content of each fraction was determined. Degree of humification (DH $\%$ ) was calculated by using the following equation (Equation 1).

$$
\mathrm{DH}(\%)=\left(\frac{\mathrm{HA}+\mathrm{FA}}{\mathrm{TEC}}\right) \times 100
$$

Carbon dioxide produced by the compost is trapped by sodium hydroxide as sodium carbonate (Thompson et al, 2001). As shown in Figure 1, the carbon dioxide was trapped in a sodium hydroxide $(1 \mathrm{M} \mathrm{NaOH})$ wash bottle $(1 \mathrm{~L})$ and then measured daily by titration with $1 \mathrm{M} \mathrm{HCl}$ to a phenolphthalein endpoint, after adding excess $1 \mathrm{M} \mathrm{BaCl}_{2}$.

A water extract was prepared for the determination of the seed germination index (GI). Fresh compost samples taken at mixed with deionized water at a 1:10 ratio (mass ratio) and shaken for $1 \mathrm{~h}$, then centrifuged at $4000 \mathrm{rpm}$ for $20 \mathrm{~min}$ and filtered through $0.45 \mu \mathrm{m}$ membrane filters. The GI was determined in triplicate using ten tomato seeds (Lycopersicon esculentum L.) and a water extract. Eight millilitre of the water 
extract was pipetted into Petri dishes $(10 \mathrm{~cm}$ in diameter) packed with a piece of filter paper. Ten seeds were evenly scattered on the filter paper and incubated at $20 \pm 1^{\circ} \mathrm{C}$ for $48 \mathrm{~h}$ in the dark. Deionized water was used as a control. The GI was calculated by using the follows equation (Equation 2) (Rui et al, 2012).

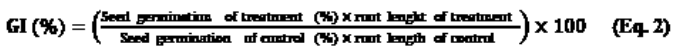

\subsection{Statistical analysis}

Data were analyzed by a one-way analysis of variance (ANOVA); the LSD- $t$ test was used for significant difference testing. Pearson's correlation coefficient was used for the analysis of bivariate correlations. The SPSS 11.5 software for Windows was used for all statistical analyzes (SPSS Inc., 2002).

\section{Results and Discussion}

\subsection{Temperature and carbon dioxide}

Figure 2 shows the changes in the ambient temperature and composting temperature. The ambient temperature ranged from $20^{\circ} \mathrm{C}$ to $30^{\circ} \mathrm{C}$. The composting materials went through the three typical degradation phases: mesophilic, thermophilic and curing. Increase temperature at the beginning may be due to high available carbon content which it provides a favourable condition for the growth and biological activity of microorganisms (Novinscak et al, 2007). The temperature tends to decrease after the thermophilic phase due to the loss of substrate and a decrease in microbial activity (Ogunwande et al, 2008). Because of the metabolism of the psychrophilic and mesophilic microbes, the temperatures of treatments with moderate and high ARs reached the thermophilic phase $\left(>55^{\circ} \mathrm{C}\right)$ within the first $1-7 \mathrm{~d}$. The temperatures of the treatments with the low AR rose more slowly but remained above $60{ }^{\circ} \mathrm{C}$ for the longest time. This difference is because the lowest AR leads to a lower organic degradation rate and lower losses of moisture and heat. The thermophilic phase $\left(>55^{\circ} \mathrm{C}\right)$ for all treatments lasted longer than $7 \mathrm{~d}$. After the easily degradable compounds were depleted, the composting entered the curing phase and the temperature slowly dropped (Shen et al, 2011). The statistical analysis showed that, the AR had a significant influence on the change in temperature $(p=0.021)$, but the MC and the $\mathrm{C} / \mathrm{N}$ ratio did not significantly affect the temperature $(p=0.611, \mathrm{p}=0.133)$. The $\mathrm{CO}_{2}-\mathrm{C}$ concentrations in the outlet air during composting (Figure 2) were significantly correlated to their temperatures ( $R=0.350-0.941, p=0.010-0.024)$. Carbon dioxide was mainly emitted during the thermophilic period because of the degradation of easily degradable carbon under vigorous bacterial and fungal activity. During the curing period, $\mathrm{CO}_{2}$ emissions are related to the degradation of complex organic molecules such as lignin and lignocelluloses by some fungi and actinomycetes (Kumar et al, 2010). After composting, the $\mathrm{CO}_{2}$ emissions from $\mathrm{T} 1$ to $\mathrm{T} 9$ were $180-470 \mathrm{~g}$ $\mathrm{CO}_{2}-\mathrm{C} \mathrm{kg}^{-1}$ of initial total carbon. Treatment $\mathrm{T} 8 \mathrm{had}$ the lowest $\mathrm{CO}_{2}$ emissions indicating that a high $\mathrm{MC}$ and a low $\mathrm{C} / \mathrm{N}$ ratio restricted organic degradation even at a high AR. This low degradation rate occurred because the large pieces of waste material (diameter $3 \mathrm{~cm}$ ) combined with a low $\mathrm{C} / \mathrm{N}$ ratio and high $\mathrm{MC}$ reduced the oxygen diffusion rate into the interior of the waste particles, reducing microbial activity (Shen et al, 2011; Rui et al, 2012). Also, the statistical analysis showed that neither the $\mathrm{AR}, \mathrm{C} / \mathrm{N}$ ratio nor the $\mathrm{MC}$ had a significant influence on $\mathrm{CO}_{2}$ emissions. Wang et al. (2004) suggested that, the composts from cattle and pig manure were more stable when the respiration rates were below $1 \mathrm{mg} \mathrm{CO}_{2}-\mathrm{C} \mathrm{g}^{-1} \mathrm{DM} \mathrm{d}^{-1}$. Higher $\mathrm{CO}_{2}$ emissions indicate unstable compost that needs further decomposition. On day 40 , the $\mathrm{CO}_{2}$ emissions 
from treatments $\mathrm{T} 1, \mathrm{~T} 3, \mathrm{~T} 5, \mathrm{~T} 8$ and $\mathrm{T} 9$ were 0.60 $0.90 \mathrm{mg} \mathrm{CO}_{2}-\mathrm{C} \mathrm{g}^{-1} \mathrm{DM} \mathrm{d}^{-1}$, but the emissions for the other treatments were $1.30-2.50 \mathrm{mg} \mathrm{CO}_{2}-\mathrm{C} \mathrm{g}^{-1} \mathrm{DM}$ $\mathrm{d}^{-1}$. The low $\mathrm{CO}_{2}$ emission rate for treatment $\mathrm{T} 8$ was related to its low activity.
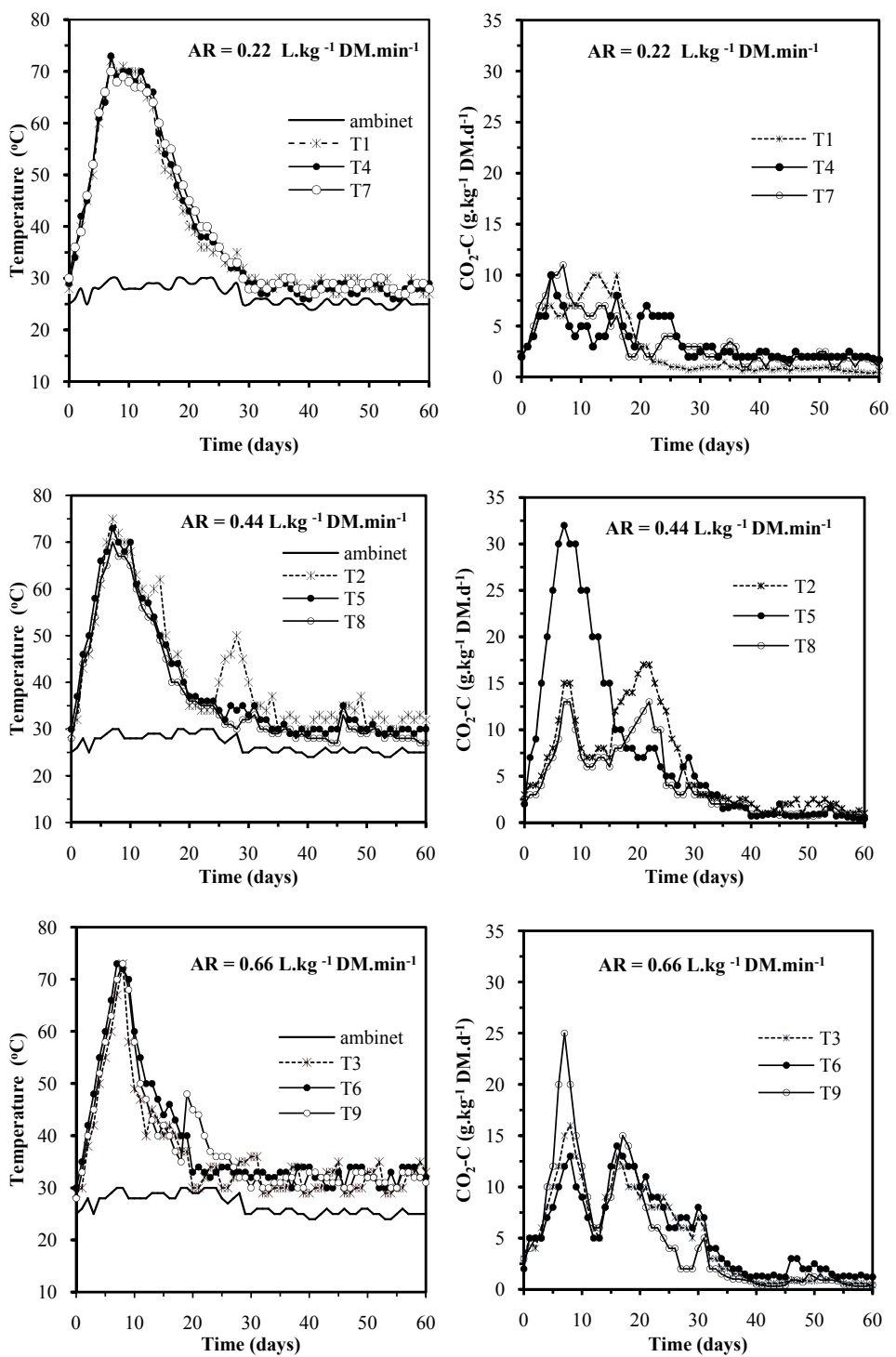

Figure 2. Temperature of the compost in the vessel and $\mathrm{CO}_{2}$ content in the outlet air during composting (AR: aeration rate). 


\subsection{Total organic carbon and total nitrogen}

The total organic carbon (TOC) contents of all treatments decreased during composting ( is shown in Figure 3). As with the $\mathrm{CO}_{2}$ emissions, the rates of decrease were greater during the thermophilic phase (60-95\% of the total carbon loss) and less during the curing phase. Decreasing TOC content during composting process could be related to the mineralization of the organic matter by microorganisms. A total of $36-56 \%$ of the initial TOC (369-406 $\left.\mathrm{g} \mathrm{kg}^{-1} \mathrm{DM}\right)$ was lost at the end of composting (Table 3). Higher TOC losses occurred with the higher AR except for treatment T8, which had low activity. At the end of composting, $\mathrm{CO}_{2}$ was the main source of carbon loss, accounting for $70-85 \%$ of the total carbon losses. The remaining carbon losses were caused by the emission of $\mathrm{CH}_{4}$ and other volatile organic compounds (such as methyl mercaptan and dimethyl sulphide) (Hanajima et al, 2010). The statistical analysis showed that AR ( $p$ $=0.032)$ had the most significant influence on the decreasing of TOC compared with the $\mathrm{MC}(p=0.71)$ and $\mathrm{C} / \mathrm{N}$ ratio $(p=0.42)$. There was a significant difference between the treatments with low and high ARs ( $p=$ 0.012 ), but no significant differences between those two treatments and the moderate $\operatorname{AR}(p=0.075, p=$ $0.033)$. Thus, the obtained data conclude that higher ARs can cause higher organic carbon losses. These results are in agreement with those obtained by Rui et al. (2012). Figure 3 shows the variation in the TN content. The TN contents of treatments with moderate and high ARs decreased during the thermophilic phase because of intensive $\mathrm{NH}_{3}$ volatilization, but only minor changes in $\mathrm{TN}$ were observed for treatments at the low AR. The TN increased after the thermophilic phase for all treatments except $\mathrm{T} 8$, because the rate of $\mathrm{N}$ loss as $\mathrm{NH}_{3}$ was slower than, the rate of dry matter loss as $\mathrm{CO}_{2}$ and water evaporation (Huang et al, 2006). The TN in treatment $\mathrm{T} 8$ decreased slightly, but had little variation after day 30 , which is related to the minor losses of $\mathrm{NH}_{3}$ by aeration coupled with the low carbon and vapour emissions due to the inactive state of the material. At the end of composting, the TN losses were $19 \%$ to 45\% (Table 3). The statistical analysis showed that AR ( $p=0.041)$ had the most significant influence on the nitrogen losses compared with the MC $(p=0.725)$ and $\mathrm{C} / \mathrm{N}$ ratio $(p=0.437)$. There was a significant difference between the treatments with low and high ARs ( $p$ $=0.016$ ), but no significant differences between those two treatments and the moderate $\operatorname{AR}(p=0.472, p=$ 0.342). Thus, we conclude that higher ARs can cause higher nitrogen losses.

\subsection{Humic substances and humification parameters}

The total extractable organic carbon (TEC) and humified humic-like substances (HA + FA) content is detailed in Figure 4. This figure shows that TEC of the compost displayed a similar trend to TOC, which decreased rapidly at the first 15 days after composting process initiation. It was followed by a gradual decrease to below after 45 days until the end of incubation period (60 days). The analytical results in Figure 4 show that, the TEC level decreased from 184 to $147 \mathrm{~g} / \mathrm{kg}$ in T1, from 192 to $155 \mathrm{~g} /$ $\mathrm{kg}$ in T2, from 199 to 172 in T3, from 192 to $163 \mathrm{~g} / \mathrm{kg}$ in T4, from 202 to $180 \mathrm{~g} / \mathrm{kg}$ in T5, from 180 to 143 in T6, from 203 to $180 \mathrm{~g} / \mathrm{kg}$ in T7, from 185 to $167 \mathrm{~g} / \mathrm{kg}$ in T8 and from 190 to $160 \mathrm{~g} / \mathrm{kg}$ in T9 treatment. The highest decreasing rate of TEC appeared in T6 (66 L.kg ${ }^{-1}$ Dm.min ${ }^{-1}$ $\mathrm{AR}, 16 \mathrm{C} / \mathrm{N}$ and $65 \% \mathrm{MC}$ ), while the lowest one noticed in T8 characterized by 0.44 L.kg-1 Dm.min ${ }^{-1}, 16 \mathrm{C} / \mathrm{N}$ and $70 \%$ MC. The statistical analysis showed that $\mathrm{AR}(p=$ $0.021)$ and $\mathrm{C} / \mathrm{N}$ ratio $(p=0.035)$ had the most significant influence on the TEC losses compared with the MC ( $p$ $=0.725)$. There was a significant difference between the treatments with low and high ARs $(p=0.016)$, but no significant differences between those two treatments and the moderate $\mathrm{AR}(p=0.714, p=0.342)$. Also, high sig- 
nificant difference was occurred between the treatments with low and high $\mathrm{C} / \mathrm{N}(p=0.013)$, and no significant differences between those two treatments and the moderate $\mathrm{C} / \mathrm{N}(p=0.632, p=0.542)$. Thus, we conclude that higher ARs and low $\mathrm{C} / \mathrm{N}$ ratio can accelerate the degradation of organic carbon, and consequently cause higher TEC losses. As reported by Ciavatta et al. (1990) and Marco et al. (2004), different studied treatments confirmed that TEC decreased predominantly during composting due to the intense mineralization process. TEC fraction included all the easily mineralizable organic fractions and other more humified and hence more biodegradation resistant fractions (Huang et al, 2006). The content of humic acid-like substances (HA + FA) in the composts increased during the first phase (15 days), which it were decreased slightly after that until the end of incubation period (Figure 4). This increasing in the first phase could be due to either the formation of humic acid-like substances or the separation of these substances from other more complex carbon compounds (Huang et al, 2006). While decreasing rate in the latter phase may be related to high amount of insoluble compounds (Figure 4). Throughout composting, the highest values of humic-like substances (HA+FA) accompanied the highest $\mathrm{C} / \mathrm{N}$ ratio treatments (T3, T5, $\mathrm{T} 7)$, followed by moderate $\mathrm{C} / \mathrm{N}$ ratio (T2, T4, T9) and finally $\mathrm{C} / \mathrm{N}$ ratio $(\mathrm{T} 1, \mathrm{~T} 6, \mathrm{~T} 8)$ treatments. The statistical analysis showed that $\mathrm{C} / \mathrm{N}$ ratio $(p=0.041)$ had the most significant influence on the humic-like substances (HA+FA) variations compared with the ARs ( $p=0.625)$ and MC $(p=0.537)$. Also, the compost with the highest initial $\mathrm{C} / \mathrm{N}$ ratio was significantly $(P=0.021)$ different from the other treatments and had the highest values of humic-like substances. There is no significant difference between the treatments with low and high ARs ( $p=$ 0.651 ) and between those two treatments and the moderate ARs $(p=0.802, p=0.402)$. Likewise, there are no significant differences between the treatments under different moisture levels. However, high significant differences were observed between either T3 (60\% moist) or
$\mathrm{T} 5$ (65\% moist) and $\mathrm{T} 7$ (70\% moist) $\mathrm{MC}(p=0.032, p=$ $0.022)$, but no significant differences between $\mathrm{T} 3$ and T5 MC $(P=0.633)$. Continuously, the degree of humification (DH, \%) of compost samples is illustrated in Figure 5 , which it was increased with increasing time (except T8). Composts $\mathrm{T} 8$ showed a low maturation level, since $\mathrm{DH} \%$ was 58.6; composts T2, T3, T5, T6 and T9 resulted to have reached a high maturation level $(\mathrm{DH} \%>70)$, while composts $\mathrm{T} 1, \mathrm{~T} 4$ and $\mathrm{T} 7$ showed intermediate values of $\mathrm{DH} \%$ (68.0, 65.0 and 63.3 respectively), indicating an incomplete stabilization of this composts. Throughout composting, the highest values of $\mathrm{DH} \%$ accompanied the highest $\mathrm{C} / \mathrm{N}$ ratio treatments (T3, T5, T7) and/or the moderate $\mathrm{C} / \mathrm{N}$ ratio $(\mathrm{T} 2, \mathrm{~T} 4, \mathrm{~T} 9)$, while the lowest $\mathrm{C} / \mathrm{N}$ ratio treatments (T1, T6, T8) comes later. Also, high DH values observed for the treatments that have the highest aeration rate $\left(0.66 \mathrm{~L} . \mathrm{kg}^{-1} \mathrm{DM} \cdot \mathrm{min}^{-1}\right)$, while the lowest one recorded to the lowest aeration rate $\left(0.22 \mathrm{~L}_{\mathrm{kg}}{ }^{-1} \mathrm{DM} \cdot \mathrm{min}^{-1}\right)$. However, the treatments treated with moderate moisture (65\%) gave the highest values of DH compared with the other two moisture rates ( $60 \%$ and $70 \%)$.

\subsection{Germination index (GI)}

The GI is a sensitive indicator of maturity and phytotoxicity (Rui et al, 2012). Figure 6 shows the changes in GI for all treatments. The GIs of all treatments decreased slowly during the early phase. This drop may be attributed to the production of low molecular weight short chain volatile fatty acids (primarily acetic acid) and the release of toxic concentration of ammonia (Fang et al, 1999). The GIs increased with the decomposition of these toxic materials. The statistical analysis showed that the $\mathrm{C} / \mathrm{N}$ ratio had a significant influence on GI $(P=0.005)$, but MC $(P=$ $0.762)$ and $\mathrm{AR}(P=0.864)$ were not important influential factors. No significant differences were found between the treatments with $\mathrm{C} / \mathrm{N}$ ratios of 19 and $22(P=0.331)$, but both of those were significantly different from the treatments with a $\mathrm{C} / \mathrm{N}$ ratio of $16(P=0.003, P=0.005)$. 
A GI of more than $80 \%$ indicates phytotoxic-free and mature compost (Rui et al, 2012). At the end of composting (60 days), the GIs for treatments with a $\mathrm{C} / \mathrm{N}$ ratio of 22 $(\mathrm{T} 3, \mathrm{~T} 5, \mathrm{~T} 7)$ were higher than treatments with a $\mathrm{C} / \mathrm{N}$ ratio of 19 (T2, T4, T9) at the same AR, except the lowest aeration rate where the treatment with $\mathrm{C} / \mathrm{N}$ ratio of 19 was higher than the treatment with a $22 \mathrm{C} / \mathrm{N}$ ratio. While both the treatments with $\mathrm{C} / \mathrm{N}$ ratios of 19 and 22 were much higher than treatments with a $\mathrm{C} / \mathrm{N}$ ratio of 16 . The GIs of the treatments at the lowest $\mathrm{C} / \mathrm{N}$ ratio $(\mathrm{T} 1, \mathrm{~T} 6, \mathrm{~T} 8)$ were
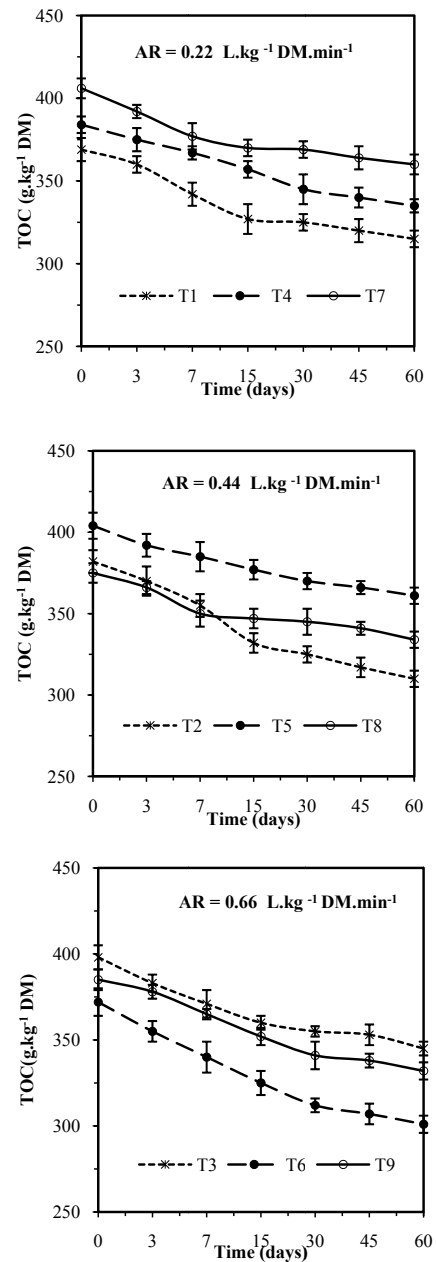

Figure 3. Total organic carbon (TOC) and total nitrogen (TN) during composting (AR: aeration rate).Values are means \pm standard error $(n=3)$.
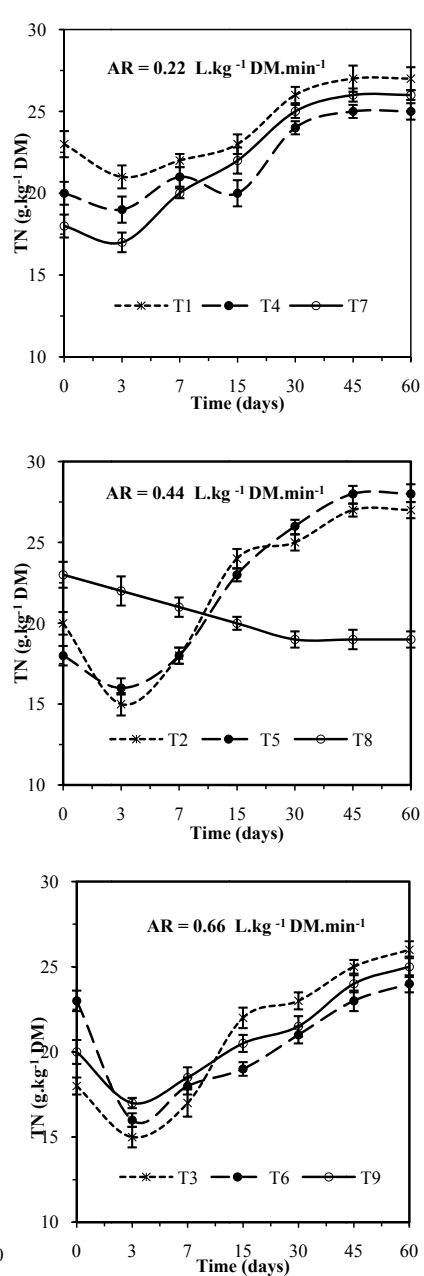

$57-67 \%$, suggesting that a longer time was required to form mature compost when a low $\mathrm{C} / \mathrm{N}$ ratio was used. This result is similar to that found by Huang et al. (2006), who used two static aerobic piles (initial $\mathrm{C} / \mathrm{N}$ ratios of 15 and 30) to compost pig manure, and found that at day 63 , the GIs were $46 \%$ and $85 \%$ for $\mathrm{C} / \mathrm{N}$ ratios of 15 and 30 , respectively. The GIs of all treatments with moderate and high $\mathrm{C} / \mathrm{N}$ ratios except $\mathrm{T} 7$ exceeded $80 \%$. The high $\mathrm{MC}$ (70\%) and low $\mathrm{AR}\left(0.22 \mathrm{~L} \mathrm{~kg}^{-1} \mathrm{DM} \mathrm{min}{ }^{-1}\right)$ in treatment $\mathrm{T} 7$ restricted the decomposition of toxic compounds. 

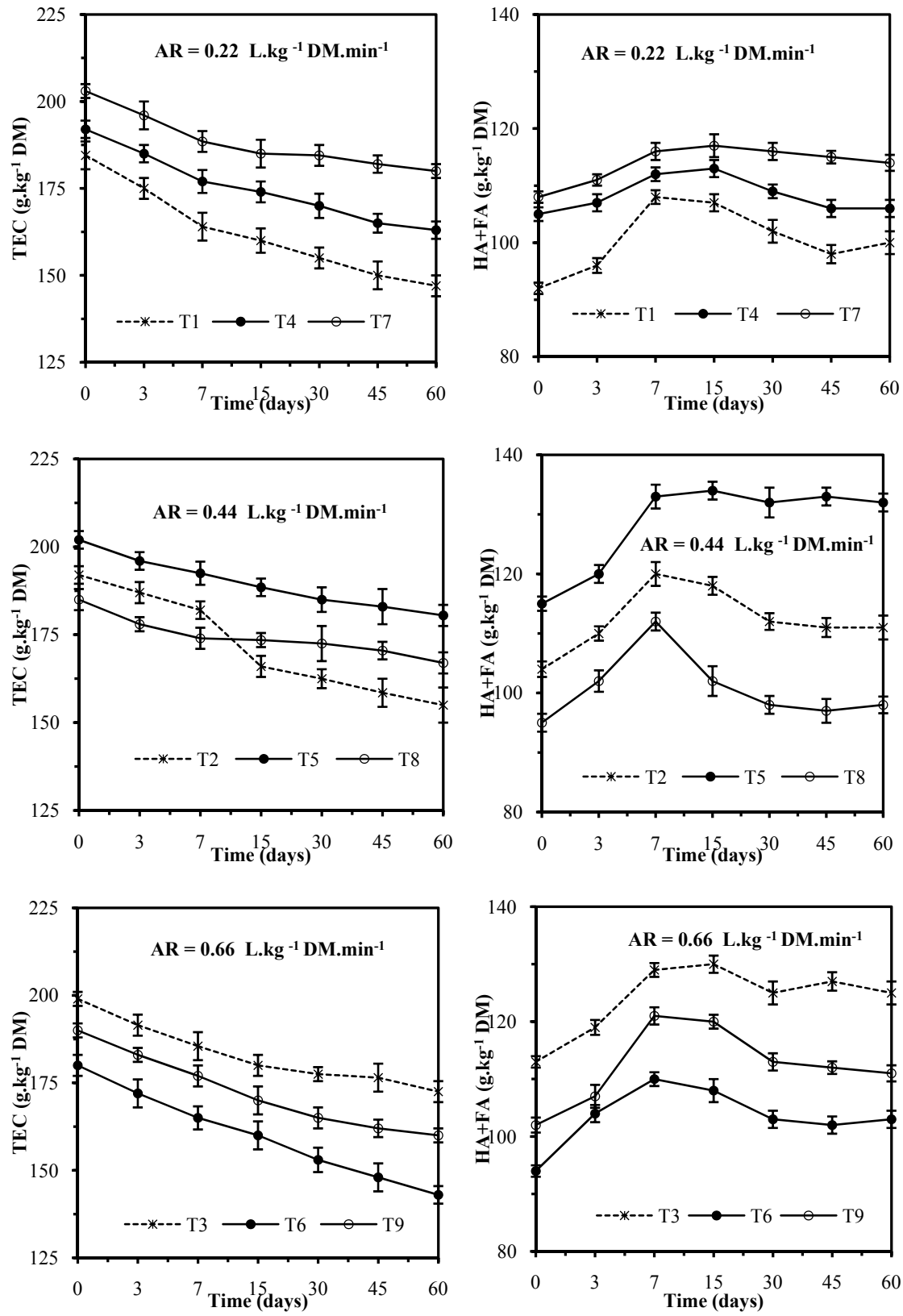

Figure 4. Total extractable carbon (TEC) and humic and fulvic acids (HA+FA) during composting (AR: aeration rate).Values are means \pm standard error $(n=3)$. 

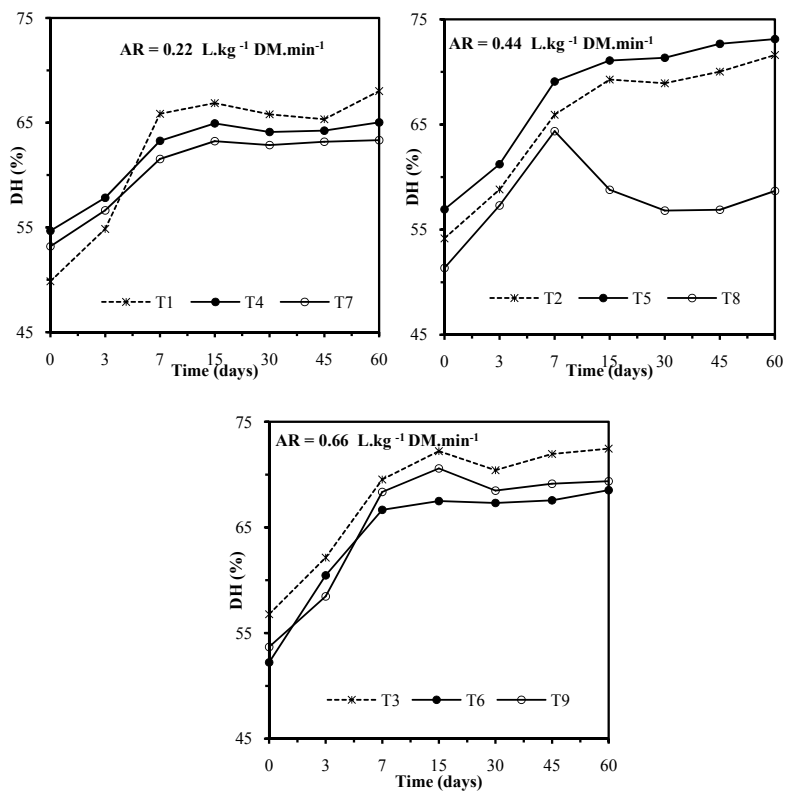

Figure 5. Degree of humification $(\mathrm{DH})$ during composting (AR: aeration rate)
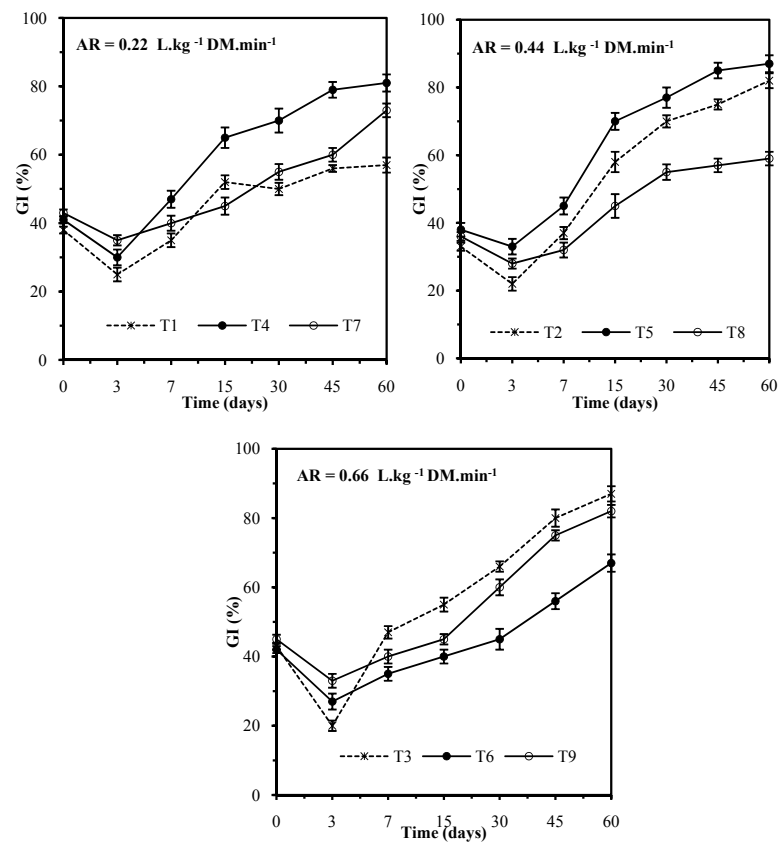

Figure 6. Germination index (GI) during composting (AR: aeration rate). Values are means \pm standard error $(n=3)$. 


\section{Conclusions}

Aeration rates (AR), moisture contents (MC) and $\mathrm{C} / \mathrm{N}$ ratios during composting of maize stalks and cow feces could be used as suitable indicators for evolution of the compost stability and maturity. The AR was the major factor influencing the stability of compost, while the initial $\mathrm{C} / \mathrm{N}$ ratio mainly influenced the maturity of the final compost. The MC can affect the quality of compost but not significantly. To economically treat the increasing quantities of cow manure, composting with an $\mathrm{AR}$ of $0.44 \mathrm{~L} \mathrm{~kg}^{-1} \mathrm{DM} \mathrm{min}{ }^{-1}$ and a $\mathrm{C} / \mathrm{N}$ ratio of 19 is recommended with a $\mathrm{MC}$ ranging from $60 \%$ to $70 \%$.

\section{Acknowledgements}

The author acknowledges financial and scientific support provided by the Faculty of Agriculture, Menoufia University, Egypt. Many thanks are extended to Prof. Dr. E. A. Abou Hussien, Head, Department of Soil Science, Fac. of Agric. Menoufia Uni., Egypt, for his encouragement while preparing this paper.

\section{References}

Badawi, A., Tantawi, B.A. 2004. Egypt Strategies and Achievement in the Utilization of Agricultural Residues. Agricultural Research Centre, Giza, Egypt.

Bernal, M.P., Alburquerque, J.A., Moral, R. 2009. Composting of animal manures and chemical criteria for compost maturity assessment. a review. Bioresource Technology. 100, 5444-5453.

Ciavatta, C., Govi, M., Vittori, A.L., Sequi, P. 1990. Characterization of humified compounds by extraction and fractionation on solid polyvinylpyrrolidone. Journal of Chromatography. 509, 141146.
Diaz, M.J., Madejon, E., Lopez, F., Lopez, R., Cabrera, F. 2002. Optimization of the rate vinasse/ grape marc for co-composting process. Process Biochemistry. 37, 1143-1150.

Fang, M., Wong, J.W.C., Ma, K.K., Wong, M.H. 1999. Co-composting of sewage sludge and coal fly ash: nutrient transformations. Bioresource Technology. 67, 19-24.

Gao, M., Li, B., Yu, A., Liang, F., Yang, L., Sun, Y. 2010. The effect of aeration rate on forced-aeration composting of chicken manure and sawdust. Bioresource Technology. 101, 1899-1903.

Govi, M., Ciavatta, C., Gessa, C. 1993. Evolution of organic matter in sewage sludge: a study based on the use of humification parameters and analytical electrofocusing. Bioresource Technology. 44, 175-180.

Hanajima, D., Kuroda, K., Morishita, K., Fujita, J., Maeda, K., Morioka, R. 2010. Key odor components responsible for the impact on olfactory sense during swine feces composting. Bioresource Technology. 101, 2306-2310.

Huang, G.F., Wu, Q.T., Wong, J.W.C., Nagar, B.B. 2006. Transformation of organic matter during co-composting of pig manure with sawdust. Bioresource Technology. 97, 1834-1842.

Kumar, M., Ou Yan, L., Lin, J.G. 2010. Co-composting of green waste and food waste at low $\mathrm{C} / \mathrm{N}$ ratio. Waste Management. 30, 602-609.

Liang, C., Das, K.C., McClendon, R.W. 2003. The influence of temperature and moisture contents regimes on the aerobic microbial activity of a biosolids composting blend. Bioresource Technology. 86, 131-137.

Marco, G., Claudio, C., Carlo, G. 2004. Evolution of organic matter from sewage sludge and garden trimming during composting. Bioresource Technology. 91, 163-169. 
Novinscak, A., Surette C., Filion, M. 2007. Quantification of Salmonella spp. in composted biosolids using a TaqMan qPCR assay. Journal of Microbiology Methods. 70, 119-126.

Ogunwande, G.A., Osunade, K.O., Adekalu, K.O., Ogunjimi, L.A.O. 2008. Nitrogen loss in chicken litter compost as affected by carbon to nitrogen ratio and turning frequency. Bioresource Technology. 99, 7495-7503.

Page, A.L., Miller, R.H., Keeney, D.R. 1982. Method of Soil Analysis. Part 2. Chemical and Microbiological Properties, No. 9, second ed. ASA, SSSA Published. Madison, Wisconsin, USA.

Petric, I., Selimbašic,' V. 2008. Development and validation of mathematical model for aerobic composting process. Chemical and Engineering Journal. 139, 304-317.

Rui, G., Guoxue, L., Tao, J., Frank, S., Tongbin, C., Yuanqiu, Z., Yujun, S. 2012. Effect of aeration rate, $\mathrm{C} / \mathrm{N}$ ratio and moisture content on the stability and maturity of compost. Bioresource Technology. 112, 171-178.
Said-Pullicino, D., Erriquens, F.G., Gigliotti, G. 2007. Changes in the chemical characteristics of waterextractable organic matter during composting and their influence on compost stability and maturity. Bioresource Technology. 98, 1822-1831.

Shen, Y., Ren, L., Li, G., Chen, T., Guo, R. 2011. Influence of aeration on $\mathrm{CH}_{4}, \mathrm{~N}_{2} \mathrm{O}$ and $\mathrm{NH}_{3}$ emissions during aerobic composting of a chicken manure and high $\mathrm{C} / \mathrm{N}$ waste mixture. Waste Management. 31, 33-38.

SPSS Inc., 2002 . SPSS for Windows (11.5). Chicago, IL: SPSS Inc.

Thompson, W.H., Leege, P., Millner, P., Watson, M. 2001. Test methods for the examination of composting and compost (TMECC). U.S. Composting Council. Holbrook, New York.

Wang, P., Changa, C.M., Watson, M.E., Dick, W.A., Chen, Y., Hoitink, H.A.J. 2004. Maturity indices for composted dairy and pig manures. Soil Biology Biochemistry. 36, 767-776. 